\title{
Vyacheslav Ivanov's Concept of Dionysianism: From Symbolist Theory to Philosophy of Art
}

\section{Концепция дионисийства Вячеслава Иванова: от теории символизма к философии искусства*}

\author{
А.А. Доронина \\ Национальный исследовательский университет \\ «Высшая школа экономики», Москва, Россия
}

DOI: $10.30727 / 0235-1188-2019-62-3-25-39$

Оригинальная исследовательская статья

\section{Аннотация}

Концепт дионисийства становится основополагающим в творчестве русского символиста Вячеслава Иванова в 1900-1910-х гг., что находит свое выражение в построении оригинальной теории символизма. Символизм для поэта и мыслителя оказывается своеобразной философией искусства, претендующей на завершенность. Теория символизма Иванова вбирает в себя эстетику, этику, теорию познания, философию культуры. Концепция дионисийства, формирующаяся в процессе филологических изысканий Иванова в области греческой религии, отмечена влиянием Ф. Ницше. Однако под воздействием русской религиозно-философской мысли Иванов фактически приходит к противоположным, по сравнению с Ницше, выводам, касающимся как филологического, так и культурфилософского аспекта происхождения трагедии. В статье рассматривается восприятие Ивановым философии Ф. Ницше, а также расхождение Ницше и Иванова в понимании мифологемы Диониса. Особое внимание в статье уделено рассмотрению теории реалистического символизма, понятого Ивановым как символизм религиозный, центральной идеей которого становится стремление к обретению realia in rebus, ноуменальной сути вещей. В статье также обсуждаются представления Иванова о сближении мифа Диониса с религией христианства, особенности понимания философом культа Диониса, а также основные выводы Иванова, сделанные в отношении дионисийского культа и христианства.

Ключевые слова: дионисийство, Дионис, символ, миф, реалистический символизм, религиозный символизм, Ницше, трагедия.

* Исследование выполнено за счет средств гранта Президента Российской Федерации МК-3702.2019.6 «Экуменистические проекты русских мыслителей второй половины XIX в. - начала XX в.». 
Доронина Анна Александровна - академический аспирант Школы философии Национального исследовательского университета «Высшая школа экономики», стажер-исследователь Международной лаборатории исследований русско-европейского интеллектуального диалога НИУ ВШЭ.

adoronina@hse.ru

http://orcid.org/0000-0002-6443-5551

Для цитирования: Доронина А.А. (2019) Концепция дионисийства Вячеслава Иванова: от теории символизма к философии искусства // Философские науки. 2019. Т. 62. № 63. С. 25-39.

DOI: $10.30727 / 0235-1188-2019-62-3-25-39$

\section{Vyacheslav Ivanov's Concept of Dionysianism: From Symbolist Theory to Philosophy of Art}

\section{A.A. Doronina}

National Research University Higher School of Economics, Moscow, Russia

DOI: $10.30727 / 0235-1188-2019-62-3-25-39$

Original research paper

\section{Abstract}

The concept of Dionysianism becomes fundamental in the work of Russian symbolist Vyacheslav Ivanov in the 1900-1910s, which led him to development of an original theory of symbolism. For this poet and thinker, symbolism becomes an integral philosophy of art. Ivanov's theory of symbolism incorporates aesthetics, ethics, theory of knowledge, philosophy of culture. The concept of Dionysianism formed in the process of Ivanov's philological studies of Greek religion was marked by the influence of F. Nietzsche. However, under the influence of Russian religious and philosophical thought, Ivanov comes to conclusions that contradicted Nietzsche, concerning both philological and cultural-philosophical aspects of the origin of the tragedy. The present article discusses Ivanov's perception of F. Nietzsche's philosophy as well as points of divergence between Nietzsche and Ivanov in understanding the mythologem of Dionysus. Particular attention is paid to the theory of realistic symbolism, understood by Ivanov as a religious symbolism, with its focus on acquiring

\footnotetext{
* The research was prepared for publication with assistance of a grant of the President of the Russian Federation, "Ecumenical projects of Russian thinkers of the second half of the $19^{\text {th }}$ century - beginning of $20^{\text {th }}$ century", grant no. MK-3702.2019.6.
} 
A.A. DORONINA. Vyacheslav Ivanov's Concept of Dionysianism: From Symbolist Theory...

realia in rebus, which is, at its core, a noumenon. The article also discusses Ivanov's ideas of convergence of the myth of Dionysus with the Christian religion, his interpretation of the cult of Dionysus as well as Ivanov's main conclusions regarding the Dionysian cult and Christianity.

Key words: Dionysianism, Dionysus, symbol, myth, realistic symbolism, religious symbolism, Nietzsche, tragedy

Anna Doronina - postgraduate student at the School of Philosophy, National Research University Higher School of Economics, research assistant at the International Laboratory for the Study of Russian and European Intellectual Dialogue, National Research University Higher School of Economics.

adoronina@hse.ru

http://orcid.org/0000-0002-6443-5551

For citation: Doronina A.A. (2019) Vyacheslav Ivanov's Concept of Dionysianism: From Symbolist Theory to Philosophy of Art. Russian Journal of Philosophical Sciences $=$ Filosofskie nauki. Vol. 62, no. 3, pp. 25-39. DOI: 10.30727/0235-1188-2019-62-3-25-39

\section{Introduction}

$\mathrm{V}$. Ivanov is recognized as one of the most prominent contributors to the art of Russian Silver Age. Within the range of Ivanov's interests lay philology, anthropology, poetry, philosophy, and other types of scientific and creative work. Ivanov, on the one hand, belonged to the group of Symbolists, along with A. Blok and A. Bely, and on the other hand, was "a completely autonomous phenomenon" [Blok 1962, 7]. One researcher even called him "the eponym of the Silver Age" [Shishkin $2016,15]$. The diversity of areas of Ivanov's intellectual work sets a dual task for a historian and philosopher of culture: on the one hand, to reveal his original artistic and aesthetic concept, and, on the other hand, to conceptualize the philosophical component of his experience as such.

In our opinion, this philosophical aspect can be perceived in different areas of V. Ivanov's work. This is both an aesthetic project of symbolism and a philosophical theory of artistic work. According to many contemporaries, it was Ivanov who gave Russian symbolism its philosophy of art, creating aesthetics of symbol and myth. Inspired by materialism in his youth, he soon abandoned it in favor of the ideas of Slavophilism and Pan-Slavism. Like many of his contemporaries, V. Ivanov was influenced by Vladimir Solovyov's doctrine. Being an authority in ancient culture, mythology, and the Greek and Latin languages, Ivanov was also interested in German philosophy and 
literature. He became a follower of German culture after his acquaintance with the works of J. Böhme, A. Schopenhauer, F. Nietzsche, R. Wagner, and others. However, "in all of this, Ivanov needed such support as the traditional piety of the Russian people" [Stepun 2012, 201]. According to the philosopher F.A. Stepun, Ivanov was a Russo-European, who, "without giving up his national affiliation, went deep into and appropriated another culture... He worked like no Russian poet had done before, using... forms practiced only in Western Europe," along with original Russian forms (tale, lyrical song) [Stepun 2012, 227].

In Ivanov's work, the concept of the Dionysus myth is of particular significance, functioning as a fundamental structural element of his symbolist theory of art [Ivanov 2014, 109]. On the one hand, this concept runs through all his philosophical and poetic works, and, on the other hand, it is a sophisticated but coherent concept that Ivanov created throughout his life. At the same time, Dionysianism can be understood "as one of the symbolist aesthetic canons forming a metaphysical chronotope unique to Russian poetry," and "as a semantic plot functioning steadily in Ivanov's verse as well as in philosophical and publicist works" [Segal-Rudnik 2016, 145]. In Ivanov's response to the "crisis of individualism," we can find ideas that respond to $20^{\text {th }}$-century existentialism and, as some researchers note, to M. Heidegger's fundamental ontology [Bird 1999, 85].

In 1903, V. Ivanov lectured on the cult of Dionysus to a Russian audience in Paris. Prior to that, he had studied the history of the cult in Athens and in the library of the German Archaeological Institute. Those lectures produced an indelible impression on Z. Gippius and D. Merezhkovsky, and six months later the lectures were published in the journals Novy Put ("New Path") and Voprosy Zhizny ("Life Issues"). The lectures were rich in philological and historical detail and demonstrated a solid scientific background (despite the fact that in a prefatory note to the printed version of the lectures, Ivanov noticed that they were "short of literary and scientific rigor" [Ivanov 1904, 110]). The insightful family couple of Gippius and Merezhkovsky must have found something consonant with the time period in his lectures. The Dionysian myth reflected that epoch's significant property: its spontaneity. On the contrary, the Apollonian features seemed to be irretrievably passing away. Being a reaction to an overall social and spiritual crisis, the Russian "cultural renaissance" was implemented in multidirectional search. The tendency toward knowing oneself and recognizing another through revelation or ecstasy, where the path to an ecstatic state was regarded as a purpose 
A.A. DORONINA. Vyacheslav Ivanov's Concept of Dionysianism: From Symbolist Theory... itself, was combined with tendencies toward search for the religious truth.

Ivanov continued his studies in the field of the Hellenic religion for a long time. And then, 20 years after delivering his Russian lectures in Paris, he defended his doctoral thesis, "Dionis i Pradionisiistvo" ("Dionysus and Pra-Dionysianism"). "The research was prompted by an insistent internal need: I could overcome Nietzsche's influence in the sphere of religious consciousness only if I went that way," Ivanov acknowledged one of the reasons for continuing his research in his "Autobiographical Letter" to the Russian critic S.A. Vengerov [Ivanova 1992, 317].

\section{Critical perception of F. Nietzsche's ideas by Vyacheslav Ivanov}

We know that Nietzsche's ideas largely promoted Ivanov's reorientation in research from philological to philosophical interpretation of ancient cultural heritage. In our opinion, it was the Nietzschean philosophical concept of Dionysianism and Apollonianism that gave Ivanov a key to understanding the religion and art of Classical Antiquity, laying a foundation for his symbolist philosophy of art. To confirm that, we can quote Ivanov's acknowledgment dated 1912. Ivanov spoke of Nietzsche's impact on himself, namely his perception of the principle of distinguishing between the Apollonian and Dionysian principles as expressed in every work of art [Ivanov 1974, 190]. It can be said that for Ivanov, the Apollonian and Dionysian principles became a philosophical prism for defining the phenomenon of art as such, its essence and its boundaries. By means of these Nietzschean terms, Ivanov described the process of ascent (Apollo) and descent (Dionysus) in a creative act.

However, the influence of F. Nietzsche's ideas on V. Ivanov can be regarded as "peculiar" [Mintz 1982, 99]. Ivanov himself later reevaluated his interest in the ideas of the German philosopher in the 1890 s as "destructive." But this reappraisal of his own perception of Nietzsche and his ideas did not lead to revaluation of the German philosopher's significance for the work of the Russian symbolist. Nietzsche remained "an impulse," "a genius," "a shaper of the future" [Ivanov 1971a, 716].

Emphasizing the importance of Nietzsche for the development of philosophical ideas and the philosophical language of modern culture, A.F. Losev noted that the philologist Nietzsche "finally broke the dam and gave an amazing concept of Antiquity, which triggered active philological research of such scholars as E. Rohde, V. Ivanov and others" [Losev 1994, 27]. According to Losev, Nietzsche's "amazing concept" 
was a landmark in the views on Antiquity, and further research in that area after the author of The Birth of Tragedy: Out of the Spirit of Music could only be carried out "through recognition, or overcoming of his theory" [Losev 1994, 27]. However, it was not only philologists who were influenced by Nietzsche, and discussions of the Nietzschean views were further transferred to other fields. The German thinker created a new type of philosophical issue, and, to quote Ivanov, introduced Dionysus to the world, who in the image of the Superman is latent in an individual [Ivanov 1971a, 717].

Ivanov first read Nietzsche's book The Birth of Tragedy: Out of the Spirit of Music during his trip from Germany to Paris in 1891. Then he linked the ideas of Nietzsche with the ideas of F.M. Dostoevsky, since, according to Ivanov, both thinkers advocated a creative renewal and liberation from individuation. Ivanov admitted that he was strongly influenced by Nietzsche for a long time but then, remaining a grateful reader of his famous contemporary, he decided to overcome Nietzsche's influence. Criticism does not always seek to expose or undermine a theory. On the contrary, proceeding from Nietzsche and arguing with him, Ivanov formulated a concept of his own.

Nietzsche's early work The Birth of Tragedy was composed when he gave primary attention to aesthetics. And although Ivanov's article "Nietzsche and Dionysus" was published in 1904, by which time he was already acquainted with the other stages of Nietzsche's philosophy, Ivanov largely dwelt on The Birth of Tragedy. He was probably interested in this work, since it was at that particular time that he was intensely engaged in the issues of the "Hellenic religion," its cults, etc. It was also most likely that in the early Nietzschean concept of Dionysus, Ivanov saw the source of his subsequent theories that he would later criticize.

In the creative nature of Nietzsche's genius, Ivanov suggested the antinomy of the Dionysian and Apollonian principles. But without Apollo, without the "positive cool of the scientific spirit of the time," Nietzsche would not be comprehensible [Ivanov 1971a, 718]. Paying special attention to the cult of Dionysus, Ivanov perceived Nietzsche through the prism of ancient mythology and philology. Through the mythological image of Dionysus, Ivanov perceived Nietzsche himself: "The charm of Dionysus made him [Nietzsche. $-A$. D.] the ruler of our thoughts and the shaper of the future" [Ivanov 1971a, 716]. Ivanov was grateful to Nietzsche: "There are geniuses of pathos, and there are geniuses of goodness. Without revealing anything substantially new, they make you feel the world in a new way. Nietzsche belongs among them" 
[Ivanov 1971a, 717]. The German philosopher rediscovered "the tragic god" to people and turned his small fire - the "anguish of pessimism" into a general tragic flame. Describing the path of Nietzsche, Ivanov said, as if talking about himself: "In order to find Dionysus, he had to wander through Elysium of the pagan shadows and converse with the Hellenes in Hellenic language..." Ivanov remarked that Dionysus as an ancient god was very understandable to the people of today. In the image of "the son of God torn to pieces by the titans," the "God-man" "born of an earthly mother," the "new Dionysus," whose "mysterious appearance was the only possible will of the comforting God-descent for the Hellenes who failed to experience hope," the features of Christ are divined [Ivanov 1971a, 717]. Dionysus expresses himself only through "how," without revealing himself through "what." Dionysus is antinomic. He combines sacrifice, resurrection, consolation and "reflects the whole mystery of eternity in the living mirror of the inner superpersonal event of a frenzied soul," in Ivanov's words [Ivanov 1971a, 719]. The consequence of this is impossibility of understanding him other than through feeling, which is an inner experience, inexpressible verbally.

However, for Nietzsche, this was not so. One of Ivanov's points of criticism of the German philosopher was that Nietzsche did not define the ecstasy of Dionysus through the "how" mode. In Ivanov's view, the Dionysian principle is beyond precise determination, nor is it confined to characteristics. It can only be understood through personal experience. According to Ivanov, Nietzsche only tries to grasp the aesthetic image of Dionysus.

From the above follows the next point of Ivanov's critisism of Nietzsche: the German philosopher missed the religious content of the Dionysian cult: he "did not discern the suffering god" [Ivanov 1971a, 720]. In pursuit of establishing life "on this side," Nietzsche "knew the enthusiasm of orgies, but he did not know the weeping and moaning of passionate service" [Ivanov 1971a, 720]. From the point of view of Nietzsche, the pessimism of the Hellenes was the consequence of the fullness of their lives, and the tragic outcome of Dionysus - selfdestruction - was the legitimate consequence of his love of abundance. However, Ivanov believed that for the ancients Dionysus was rather a god announcing death consummate with resurrection.

What Ivanov and Nietzsche do share is their desire to transform modern culture [Westbrook 2009, 216]. But if Nietzsche rejects tradition, V. Ivanov, on the contrary, wants to keep this tradition. "On the one hand, Ivanov joins the Nietzschean striving for the future," as 
F. Westbrook wrote in his research of the Russian symbolist's work, "but, on the other hand, he is not ready to abandon the tradition" [Westbrook 2009, 216]. According to F. Westbrook, Ivanov overcame Nietzsche in two ways: both in religious and philosophical issues and as a philologist. We know that Ivanov, as well as Nietzsche, was concerned about the origin of the tragedy. In the tragedy, Ivanov saw a religious act, unlike Nietzsche, who, according to the Russian thinker, was focused on the aesthetic side of the issue. For Ivanov, the prototype of the tragedy was Dionysus. The tragedy became an art due to distancing from its prototype [Westbrook 2009, 200]. According to Ivanov, the tragedy originated from ecstasy. For Nietzsche, music was more important in this matter. In the view of Ivanov, the death of the tragedy is due to the increasing Apollonian energy. This partially coincided with the interpretation of Nietzsche. But according to Ivanov, a more important cause of the death of the tragedy was its gradual evolution toward the "purely" artistic, which marked a break from the religious origin.

According to Ivanov, Dionysus outgrew himself as a purely aesthetic principle, but Nietzsche remained focused on the aesthetic perception of Dionysus. Ivanov believed that Nietzsche's underestimation of the religious principle in the cult of Dionysus caused several mistakes. First of all, Nietzsche did not see Dionysus as a god (like the Greeks did). Nietzsche did not see the suffering god. And for Ivanov, suffering, death and resurrection were the most significant properties that define the god Dionysus.

Ivanov directed his criticism at Nietzsche as a philologist and as a philosopher. Of course, Ivanov's interpretation of Nietzsche's ideas continued the line of Russian religious philosophy and exists in the intellectual context of early $20^{\text {th }}$-century culture. Rejecting a purely aesthetic perception of the tragedy, Ivanov brought together Dionysianism and Christianity, essentially, on the Slavophile foundation of conciliarity, spiritual collectivism (sobornost), as opposed to individualism [Westbrook 2009].

\section{“Realistic Symbolism": Vyacheslav Ivanov's project of art philosophy}

Philological and historical studies of Dionysianism influenced all forms of Ivanov's poetic and philosophical work, while its Apollonian antithesis of Dionysianism was much less involved. Realistic symbolism became one of Ivanov's favorite themes, and it was directly related to his Dionysian theory. The matter is that Ivanov's dreams of the artist-nation (nation as an artist) were based on a modernized myth of 
Dionysus. Art must strive for harmony with the nation's soul and the symbol inherent in it and revealed by the nation's singers (geniuses) must grow into a myth. But he believed that only realistic (religious) art can become a myth, since a myth is an objective truth and cannot be revealed in idealistic art. The myth belongs to a nation, not to its creator: we do not know the authors of ancient myths.

Referring to the $19^{\text {th }}$-century German philologist F. Creuzer, Ivanov noted that in his era it was assumed that "Classical Antiquity is incomprehensible without admitting the great, international, and ancient... organization of mystical unions," where theurgists (theologians) act as teachers [Ivanov 1971b, 560]. These "unions," schools, or esoteric communities may have been the creators of some initial myths that, before the people (the crowds) knew the myths, had been sacred speeches (hieroi logoi). This remark is necessary, since about it confirms realistic symbolism as an individual (not collective) form of art, which develops into a myth.

Ivanov's theory of realistic symbolism can be understood as a basic element in a broader cultural, philosophical and also religious theory. Ivanov believed the project of realistic symbolism to be vital for culture of the future. He designed it to resist the hazards of individualism and subjectivity which could undermine the foundations of the world order and replace them with others. Ivanov's Theourgos was opposed to Nietzsche's artist-tyrant (Superman). Ivanov's concept of the artistTheourgos stemmed from the juxtaposition of religious art (as genuine symbolism) to idealistic art (artistic naturalism). The mission of the Theourgos does not only involve beauty and aesthetic experience, but "the development of the national soul" and of the "nation's destiny."

Ivanov considered "a religious impulse to artistic activity" to be the main principle of realistic symbolism [Ivanov 1979, 63]. In his case, the word "religious" is synonymous with "realistic." The task of realistic symbolism partly coincides with the religious task: to affirm the existence of a more realistic reality (Ens realissimum, that is, ultimately, God). The method of realistic symbolism is similar to the maieutic method of Socrates: to reveal the symbol of the deity in things (reality), which is the function of the Theourgos. According to Ivanov, the opposite was the method of idealistic symbolism: things (reality) are just material for the artist's whim of the will.

Some time prior to the first crisis of symbolism, Ivanov put forward the slogan a realibus ad realiora ("from visible reality and through it to the more real reality of the same things, inner and innermost" [Ivanov 1974a, 571]). The researcher of V. Ivanov's work D.N. Mitskevich notes that the article "Two Elements in Modern Symbolism," 
first published in Zolotoe Runo ("Golden Fleece") in 1908, reprinted in the 1909 book Po Zvezdam ("By the Stars"), "serves as a watershed in the evolution of Ivanov's poetics" [Mitskevich 2010, 276]. In this work, Ivanov draws a line between idealistic and realistic art and "sets some moral requirements: the development of symbolism does not need further emancipation of fantasy or of artistic forms (which idealistic art practices. A. D.); its task is more difficult: concentration on realiora, that is on the conditions of raising consciousness" [Mitskevich 2010, 276].

Myth is immanently present in the symbol. And the task of realistic art is to ascend from a thing to its symbol and from the symbol to the objective reality of the myth. In realistic symbolism, myth is "gaining." It is the ultimate truth about our being that is gained when the artist can stop searching, until conditions arise for discovery of new, deeper meanings. Myth reveals realia in rebus, that is, the reality behind things, the truth about things. The artist reveals a new myth, a new truth, and the highest task of any art (in the words of V. Solovyov, revealing the beauty and truth of supersensual reality). The artist who set himself a theurgic task, who entered into contact with the "divine unity," accomplished a spiritual feat and incorporated the newly discovered into himself, before revealing it to others. Ivanov insisted that the most important condition for such creativity was the inner supersensual and superpersonal desire for awareness of one's connection with the world.

Creation of a myth was impossible in Ivanov's time, but art is bound to strive for a myth. A myth needs a chorus to embody the idea of a symbol: "the sensual manifestation of unanimity and like-mindedness," "evidence of a real connection" [Ivanov 1971b, 558]. Such a connection becomes that integral res characterized as supra-individual. Thus, a myth is created with the help of a chorus, symbolising unity.

Establishing the principle of a realibus ad realiora, Ivanov set a specific task for artistic creativity: to rise from the sensual to the supersensual, from a material thing as the thing to its symbol or, "to manifestations of another reality" [Ivanov 1971b, 537]. Such art can affirm the meaning and interrelation of things in another reality, beyond the empirical one. Reality serves the artist as a material for asserting the supersensual reality and demonstrating it to his audience. Since religion is the only sphere where everything is integrated in all metaphysical stratification, realistic art (the principle of a realibus ad realiora) cannot ultimately fail to come into contact with it.

The principles a realibus ad realiora and realiora in rebus, according to D.N. Mitskevich, "determine opposite directions and two 
A.A. DORONINA. Vyacheslav Ivanov's Concept of Dionysianism: From Symbolist Theory... ontologically different agents of action" [Mitskevich 2010, 29]. With the first formula Ivanov indicated the direction from the thing, while with the second one - toward the thing (i.e. to the supersensual reality hidden in it). Though essentially they are opposite mystical experiences of a thing, these paths can coexist in an artist's work. If the artist identifies his selfness with realiora in rebus, which may manifest itself in love of the thing for its beauty, then it will be the "release of personality from the self-referential," i.e. escape of personality from self-isolation.

\section{Dionysian myth and Christianity in V. Ivanov's vision}

In his thesis "Dionis i Pradionisiistvo" ("Dionysus and PraDionysianism"), Ivanov defined the mythologem of Dionysus, emphasizing such characteristics as a suffering, tormented god, the god of descent, the god of self-sacrifice (for the sake of life replenishment), the god of ecstasy (frenzy, coming out of himself), "the beginning of multiplicity" [Ivanov 2015, 431]. Ivanov drew such conclusions from historical and philological studies, which in turn became the material for developing his own art theory. Dionysus was the destroyer of "individuation" which Ivanov did not accept either in his creative work or in his life [Ivanov 1971a, 718].

Like many Christian thinkers and theologians, V. Ivanov saw in Classical Antiquity promise of Christianity. For instance, in the history of religious and philosophical thought there is known a juxtaposition of Christ and Socrates, which goes back to St. Justin the Philosopher. However, Ivanov looked even deeper. He looked for Christ in the pre-religion of Dionysus.

The researcher of Ivanov's work F. Westbrook notes that, although Ivanov connected the cult of Dionysus with Christianity, he did not develop these relations in proportion to each other. With regard to the consideration of Christianity, Ivanov focused only on the texts of the Russian religious and philosophical tradition, without taking into account theologians and the Church Fathers [Westbrook 2009, 236].

The uniqueness of Ivanov's understanding of the Dionysian myth lay in the fact that he found a religious basis in it. Any other definitions of this cult, like aesthetic or allegorical, were not recognized by Ivanov.

Ivanov spoke of Dionysus as the destroyer of the limits of individuality. By defining orgies as "religious rites of the whole community," Ivanov related this concept to Russian sobornost (conciliarity) [Ivanov 2014, 14]. Though not identical, both terms seem to have one goal: going beyond the individual limited selfness and striving for wholeness. 
Evaluating the era that he was destined to witness, Nikolai Berdyaev wrote that in Ivanov's personality, individualism of the Enlightenment was opposed to the traditional Russian sobornost [Berdyaev 1989].

We emphasize once again that the cult of Dionysus was considered by Ivanov in an exclusively religious manner. He refused to reduce this myth to aesthetics or metaphors and was interested in the "how" modus, regarding the performance of this cult as his goal. In this sense, Ivanov compared Dionysus with Christ, wondering why Nietzsche had literally opposed Dionysus and Christ to each other.

Ivanov as a historian, scholar of Antiquity, philologist and to some extent an anthropologist made the assumption that during the times of the formation of Christianity ancient religions and cults could influence it. Considering the similarity of the Dionysus cult and Christianity, Ivanov only touched upon this topic and did not develop it into a rigorous, well-argumented theory. Yet the idea of bringing Dionysus closer to Christ persisted not only in his work but also in his life. In his course of lectures "Ellinskaya religia stradayushego boga" ("The Hellenic Religion of the Suffering God"), V. Ivanov noted that the comparison of Dionysus and Christ special research which, however, he never elaborated.

In "The Hellenic Religion of the Suffering God," Ivanov compared Dionysus and Christ, basing on the Gospel and the Dionysian cults. Ivanov noticed a number of coinciding descriptions and symbols, which seemed to him as a prelude, an allusion to Christianity. For example, the symbol of Dionysus and Orpheus, ichthys, coincides with the symbol of Christ, etc. However, the main thing was that the god Dionysus was tormented, suffering and underwent resurrection.

The cult of Dionysus was accompanied by passions, or performance of suffering. Ivanov also called suffering the soul of Christianity. Easter - the main festival of the Eastern Church - seemed to Ivanov to be a counterpart to the pagan holiday of Dionysus, "reviving for the world of the living" [Ivanov 2014, 14]. Ivanov wrote, "Spring was transparent to the eye of the ancients: it was death in blossom" [Ivanov 2014, 25]. According to Ivanov, the idea of death as the other side of life, was contained in the soul of the people even before "Heraclitus the Dark began to teach that life appears to be death to the dead, as death is death only to the living» [Ivanov 2014, 25].

In "The Hellenic Religion of the Suffering God," Ivanov put forward an interesting theological hypothesis with far-reaching cultural, philosophical, and theological implications. He believed that "the Asia 
Minor and Syrian communities of worshipers of the Almighty God, who retained in their beliefs many features of the cult of Dionysus Sabazios, mediated between Galilee and Dionysian Hellas and among the pagans, the Arameans' neighbors, aroused echoes of insights and hunches that had been born in the bosom of an alien worship" [Ivanov 2014, 188]. Thus, according to Ivanov, the echoes of the cult of Dionysus could merge with the "Jewish prophecies."

It is impossible to overlook the fact that Ivanov separated paganism from Christianity. He said that the pagans had not known about the original sin and its atonement. They were submerged in a state of suffering unconsciously and only had a premonition of their passions. Let us specially note that the arguments about the correlation of Christianity and the cult of Dionysus given by Ivanov in his conclusion of " The Hellenic Religion of a Suffering God" were only outlined but not elaborated.

\section{Conclusion}

Ivanov is often referred to as a Christian thinker. This is one of the definitions of the "multifaceted" Ivanov, perhaps as an integrator of his work. His theory of symbolism based on the concept of Dionysianism goes beyond the boundaries of art and becomes "more than artistic practice but rather a condition of human existence, acting as a kind of religion of salvation" [Zhukova 2017, 500]. According to Berdyaev, in Ivanov's identification of Dionysianism with Christianity, the poet manifested his desire to approach an organic culture. In 1912, Vyacheslav Ivanov wrote that "religion is not any specific content of religious beliefs, but rather a form of self-determination of an individual in his relation to the world and to God" [Ivanov 1974b, 620]. Interpreting the central thesis of Ivanov on the essence of religion, one can agree with F.A. Stepun that Dionysianism did not turn Ivanov from Christianity but, on the contrary, brought him back to religion. Life was understood by Ivanov as search for a "religious form of relationship" to oneself and to the world, that is, a connecting and subordinating form, opening up in a certain universal sense [Ivanov 1974b, 620]. The aspirations of Ivanov the mystic completely corresponded to those of Ivanov the philologist, the poet and the philosopher.

The philologist F. Zelinsky, Ivanov's contemporary, saw in the Russian thinker the dawn of "Slavic Renaissance," by which he suggested the era of the third revival, following the Renaissance and the German Renaissance of Goethe's era [Zelinsky 2002, 225]. In the view of Zelinsky, through the Slavic people (in the person of Ivanov), 
Antiquity was again called to speak to the world. "The dawn of the third Renaissance" and Ivanov, who appreciated Nietzsche's Dionysian turn, discovered a new aspect of Antiquity, previously overlooked, so we had known only one side of it [Zelinsky 2002, 225].

The conceptualization of Dionysianism became a kind of interlink in the many areas of V. Ivanov's work. Having developed his own "method" while writing the book Dionysus and Pra-Dionysianism, Ivanov developed it into his theory of symbolism [Silard 2002, 13]. He thematized the concept of Dionysianism philosophically, which makes it possible to consider the ideas of the poet and thinker as synthesis of philosophical, philological, historical and religious traditions. Formed under the influence of F. Nietzsche's philological and philosophical ideas, Ivanov's Dionysian theory found its final completion in opposing those ideas and implementing the religious pathos of Russian thought.

\section{REFERENCES}

Berdyaev N.A. (1989) Tipy religioznogo soznaniya v Rossii [Types of religious thought in Russia]. In: Berdyaev N.A. Sobranie sochineniy v 4 tomakh [Collected works in 4 volumes]. Vol. 3. Paris: YMCA-Press (in Russian).

Bird R. (1999) Martin Heidegger and Russian Symbolist Philosophy. Studies in East European Thought. Vol. 51, тo. 2, pp. 85-108.

Blok A.A. (1962) Tvorchestvo Vyacheslava Ivanova [Work of Vyacheslav Ivanov]. In: Blok A.A. Sobranie sochineniy v 8 tomakh [Collected works in 8 volumes]. Vol. 5. Moscow: Gosudarstvennoe izdatel'stvo khudozhestvennoy literatury (in Russian).

Ivanov V.I. (1904) Ellinskaya religiya stradayuschego boga [The Hellenic religion of a suffering god]. Novy Put'. 1904. No. 1, pp. 110-124 (in Russian).

Ivanov V.I. (1971a) Dve stikhii v sovremennom simvolizme [Two elements in modern symbolism]. In: Sobranie sochineniy v 4 tomakh [Collected works in 4 volumes]. Vol. 1. Brussels: Foyer Oriental Chretien (in Russian).

Ivanov V.I. (1971b) Nietzsche i Dionis [Nietzsche and Dionysus]. In: Sobranie sochineniy v 4 tomakh [Collected works in 4 volumes]. Vol. 1. Brussel: Foyer Oriental Chretien (in Russian).

Ivanov V.I. (1974a) Manera, litso, stil' [Manner, face, style]. In: Sobranie sochineniy v 4 tomakh [Collected works in 4 volumes]. Vol. 2. Brussels: Foyer Oriental Chretien (in Russian).

Ivanov V.I. (1974b) Ekskurs II. Estetika i ispovedanie [Excursus II. Aesthetics and confession]. In: Sobranie sochineniy v 4 tomakh [Collected works in 4 volumes]. Vol. 2. Brussels: Foyer Oriental Chretien (in Russian). 
Ivanov V.I. (1979) O veselom remesle i umnom veselii [About fun craft and clever fun]. In: Sobranie sochineniy v 4 tomakh [Collected works in 4 volumes]. Vol. 3. Brussels: Foyer Oriental Chretien (in Russian).

Ivanov V.I. (2014) Ellinskaya religiya stradayuschego boga [The Hellenic religion of a suffering god]. Simvol. Issue 64, pp. 5-223 (in Russian).

Ivanov V.I. (2015) Dionis i pradionisiistvo [Dionysus and pradionisiystvo]. In: Simvol. 2015. Issue 65, pp. 7-395 (in Russian).

Ivanova L.V. (1992) Vospominaniya. Kniga ob otse [Memoirs. The book is about the father]. Moscow: Fenix (in Russian).

Losev A.F. (1994) Ocherki antichnogo simvolizma i mifologii [Sketches of ancient symbolism and mythology]. Moscow: Mysl' (in Russian).

Mintz Z.G. (1982) A. Blok i Vyach. Ivanov. Gody pervoi russkoi revolutzii [A. Blok i Vyach. Ivanov. The years of the first Russian revolution]. - URL: http://www.ruthenia.ru/reprint/Minz_Blok_Ivanov. pdf

Mitskevich D.N. (2010) "Realiorism" Vyacheslava Ivanova ["Realiorism" of Vyacheslav Ivanov]. In: Christianity and Russian literature. The Interaction of Ethnocultural and Religious and Ethical Traditions in Russian Thought and Literature (pp. 254-342). Saint Petersburg: Nauka (in Russian).

Segal-Rudnik N.M. (2016) Dionosiistvo kak priem [Dionysianism as a method]. In: Vyach. Ivanov: pro et contra, antologiya [V.I. Ivanov: pro et contra, anthology]. Vol. 2. Saint Petersburg: TsSO (in Russian).

Shishkin A.B. (2016) Vyacheslav Ivanov v zerkalah XX veka [Vyacheslav Ivanov in the mirrors of the $20^{\text {th }}$ century]. In: Vyach. Ivanov: pro et contra, antologiya [V.I. Ivanov: pro et contra, anthology]. Vol. 1. Saint Petersburg: RHGA (in Russian).

Silard L. (2002) Germetizm i germenevtika [Hermeticism and hermeneutics]. Saint Petersburg: Izdatel'stvo Ivana Limbakha (in Russian).

Stepun F.A. (2012) Misticheskoe mirovidenie. Pyat' obrazov russkogo simvolisma [Mystical worldview. Five images of Russian symbolism]. Saint Petersburg: Vladimir Dahl' (in Russian).

Westbrook F. (2009) Dionis i dionisiyskaya tragediya. Vycheslav Ivanov: Filologicheskie i filosofskie idei o dionisiystve [Dionysus and the Dionysian tragedy. Vyacheslav Ivanov: Philological and philosophical ideas about Dionysism]. Munich: Verlad Otto Sagner (in Russian).

Zhukova O.A. (2017) Filosofiya russkoy kul'tury. Metafizicheskaya perspektiva cheloveka $i$ istorii [Philosophy of Russian culture. Metaphysical perspective of man and history]. Moscow: Soglasie (in Russian).

Zelinsky F.F. (2002) Vvedenie v filosofiyu Vyach. Ivanova [Introduction to the philosophy of Vyach. Ivanov]. In: Vyacheslav Ivanov - tvorchestvo $i$ sud'ba: $k$ 135-letiyu so dnya rozhdeniya [Vyacheslav Ivanov: creativity and fate. On the $135^{\text {th }}$ anniversary of the birth]. Moscow: Nauka (in Russian). 